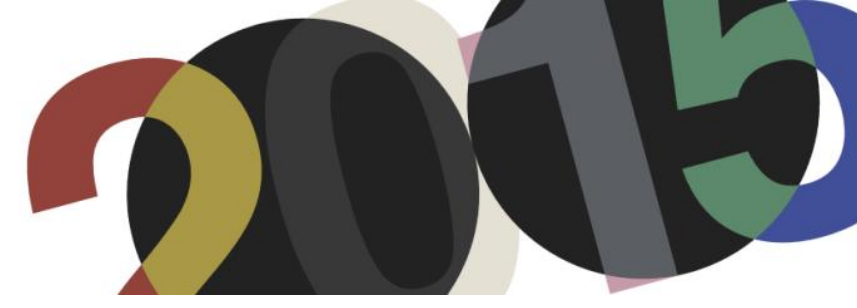

DOI: http://dx.doi.org/10.4995/LC2015.2015.689

\title{
Global Architects: a dialogue between Le Corbusier and Fernando Távora on Architecture Universality
}

\author{
S. Meleiro Lima \\ Faculdade de Arquitectura da Universidade do Porto
}

\begin{abstract}
The aim of this investigation is to present an approach to the notion of a global architect, the universality of his theory and legacy. The investigation is composed in two main stages whose goals are the following: 1) to address the notion of global architect; 2) to demonstrate the role of Le Corbusier to perform the idea of global architect and his influence in others architects, such as Fernando Távora (1923-2005), a portuguese architect recognized as the master of Álvaro Siza. The first stage, we seek to formulate a definition of global architect from the point of view of Le Corbusier's works. During the second stage we analyse and compare the positions of Le Corbusier and Távora and their projects: Ronchamp, Chandigarh and Market at Vila da Feira and Ofir Summer House. Thus, we attempt to analyse the role of Le Corbusier as a global architect and his impact on others colleagues, such as Távora who seeks to achieve the same ideal of global architect and perform a universal vision of architecture.
\end{abstract}

Resumen: El propósito de esta investigación consiste en presentar una aproximación a la idea de arquitecto global, la universalidad de su teoría y su legado. El artículo se compone en dos partes principales cuyos objetivos son los siguientes: 1) hacer una reflexión acerca de el concepto de arquitecto global; 2) aclarar el papel de Le Corbusier como un personaje que personificó el ideal de arquitecto global y mostrar como ha influenciado a muchos arquitectos, como es el ejemplo de Fernando Távora (1923-2005), un arquitecto portugués reconocido como el maestro de Álvaro Siza. En primer lugar, se procura formular una definición de arquitecto global desde el punto de vista de Le Corbusier y sus obras. Durante la segunda parte se analizan y comparan las posiciones de Le Corbusier y Fernando Távora así como sus proyectos: Ronchamp, Chandigarh, Mercado de Vila da Feira y la Casa de Verano en Ofir. Por fin, se trata de analizar la importancia y el papel de Le Corbusier como un arquitecto global y su impacto sobre otros colegas, como es el caso de Fernando Távora que intentaba lograr el mismo ideal de arquitecto global e incorporar una visión universal de la arquitectura.

Keywords: global architect; Le Corbusier; legacy; universalism; Fernando Távora.

Palabras clave: arquitecto global; Le Corbusier; legado; universalismo; Fernando Távora.

\section{Introduction}

The main objective of this investigation is to present an approach to the concept of global architect.

In this research, we aim to demonstrate a multifaceted view of the authors, which aims to transform the concept of the architect to a new ideal of global architect. Le Corbusier and Távora have a universalist point of view as a result of their deep cultural knowledge, architectural evolution and city history in order to operate in different places and circumstances. It is through their knowledge and methodology, which can then transform the place in which they operate.

The first stage, we seek to formulate a definition of global architect from the point of view of Le Corbusier's works. During the second stage we analyse and compare the positions of Le Corbusier and Távora and their projects: Ronchamp, Chandigarh and Market at Vila and Ofir Summer House. 
The latest works Le Corbusier made, allowed us to identify, a new attitude about local issues: in Chandigarh (India) or Ronchamp (France) we can observe his respect and comprehension about the site, the inhabitants culture and its circumstances. He thinks globally to act locally or in other words, he uses the modern architecture but reuses the surroundings and the culture influences in his projects.

Távora, younger architect than Le Corbusier, has met him over the last four CIAM's. In his initial projects we can notice a clear influence of Le Corbusier theories: the Five Points towards a new architecture that were enunciated in 1927 (as the use of pilotis, free floor plan, horizontal or elongated window, free façade and the roof garden), the influence of CIAM Charter toward a new urbanism from 1933 (discussed in CIAM). However, in Távora, we recognize the same attitude: although he has travelled a lot, he was always comparing the city he was visiting with his knowledge of portuguese landscape and circumstances, as we can confirm by the projects from this period, the Market at Vila da Feira or Ofir Summer House, combining the modern and local searching for a synthesis in architecture.

\section{Global Architects: the example of Le Corbusier}

“The world now has 24 solar hours at its disposal. Marco Polo took his time. Nowadays we say: 'Here are your papers Sir, your contract and your airline ticket. Leaving at six to-night, you will be in the antipodes to-morrow, (...) and, if you wish, you can start back the same evening and be home next day".

The main objective of this investigation is to highlight Le Corbusier's contribute to Modern Architecture, namely his universal perspective through world, which reflected in his disciplinarity, pedagogy and professional field.

We seek to establish relations between universality, humanism and circumstances, their delineations and strains. Besides, this investigation seeks to understand his legacy and his intemporality/timelessness.

Le Corbusier was a French-Swiss Architect (1887-1965) who changed the way we understand dwellings and the city, questioning the house as "a machine à habiter" and how can we plan our cities for tomorrow, exploring projects from Dom-ino scheme to the "immeubles-villa" and "Unité d'Habitation", that perform his first phase and also made the research on urbanism from Athens Charter, ville radieuse to the Plan Voisin planned to Paris. For this study we consider the works of Le Corbusier constructed after the Second World War. It is during the period from 1945 till 1965 that we observe his mature works and masterpieces, such as Ronchamp and La Tourette, both in France or even Chandigarh in India.

Throughout these last works, Le Corbusier was incorporating the lessons from his journeys and was looking for a synthesis between international and local circumstances. As Beatriz Colomina refers, "[...] $i$ viaggi internazionali rappresentano l'educazione architettonica di Le Corbusier, che non ha mai frequentato una scuola di architettura ${ }^{2}[\ldots]$ ”, its through his journeys that he contact with other cultures and incorporate their culture in his projects.

As we have previously mentioned, we identified in Le Corbusier latest works, a new attitude about the local issues: in Chandigarh or Ronchamp his respect and comprehension about the site, the inhabitant's culture and its

\footnotetext{
${ }^{1}$ Le Corbusier, 1960. In: Architects' Journeys Building, traveling, thinking / Los viajes de los arquietectos: construir, viajar, pensar, Ed. Craig Buckley, Pollyanna Rhee, Pamplona: T6 Ediciones, 2011.

2 Colomina, Beatriz. "Verso un architetto globale: Nel dopoguerra Le Corbusier ha transformato la professione dell'architetto. Suo complice: il jet.” In Domus. New York, 30 April 2011.
} 
circumstances. Le Corbusier uses modern architecture but reuses the surroundings and the culture influences in the projects to create a dialogue between global and local circumstances.

In this research, we aim to reveal a multifaceted view of the authors, which aims to transform the concept of the architect to a new ideal of global architect. Both architects, Le Corbusier and Távora have a universalist point of view as a result of their deep cultural knowledge, architectural evolution and city history in order to intervene and operate in different places and circumstances. It is through their knowledge and approach, which can then turn the place in which they operate.

In Távora, we recognize the same attitude: although he has travelled a lot, he was always comparing the city he was visiting with his knowledge of portuguese landscape and circumstances, as we can confirm by the projects from this period, such as the Market at Vila da Feira or Ofir Summer House, or even the Primary School at Cedro.

\section{Dialogue(s) between Le Corbusier and Fernando Távora}

"Cuando eran blancas las catedrales, por encima de las nacionalidades en formación había una idea común [...] Antes de construir universalmente las naves de la nueva civilización, un impulso común del espíritu había unido ya a los pueblos de los tiempos modernos para conducirlos, en medio de dificultades increíbles, a Jerusalén, donde se encontraba el sepulcro de un pensamiento universal ${ }^{3}$ [...]."

We selected two projects from Le Corbusier (1887-1965) last works period, from 1950 till 1965, when he died. This phase is very important to analyse because support our thesis in the scope for universality in architecture, and also is where we observe and discuss the complexity and contradiction on his work. This complexity and contradiction phenomenon was well described and analysed by Robert Venturi in his book Complexity and Contradiction in Architecture, from 1966 and we can observe the same phenomenon in the work of Fernando Távora, that usually say "The contrary in architecture is also possible/ is also true".

Both architects were concerned about synthesis problems, combining modern architecture with local materials, and looking for site integration. Chandigarh is the masterpiece of the respect to local issues: a horizontal city, entirely planned by Le Corbusier and his team. He could have planned high skyscrapers in this capital; with Unité d'habitation models to habitat building zones, but instead he proposed large horizontal buildings that respected the natural landscape. He still plans a radiant city (garden city), with a marked centre, green belts that create leisure zones to recreational activities. His assumptions on urbanism can be identified in this project, but with a few adaptions to the site circumstances.

Fernando Távora (1923-2005) was a Portuguese Architect, younger than Le Corbuiser, who participated in the last four CIAM's and also recognized as the master of Álvaro Siza.

\footnotetext{
${ }^{3}$ Le Corbusier. Cuando las catedrales eran blancas, Colección Poseidon, Ediciones Apostrofe, Barcelona: 1991, p. 53-54. "When the cathedrals were white, above nationalities concerned with themselves, there was a common idea[...]. Already, before constructing everywhere the naves of the new civilization, a common enthusiasm of spirit had brought together the peoples of modem times and had led them, through strange avatars; toward Jerusalem, where there was the seat of a universal thought[...]." Le Corbusier. When the Cathedrals Were White. New York, Toronto, London: McGraw-Hill Book Company, 1964, p. 32. Translated from the French by Francis E. Hyslop Jr.
} 
His design process starts with a process of considering local circumstances, or as Siza prefer to say "The architecture is in the place", extending them beyond the limits of the place itself, seeking to register them in a universal consciousness. His projects since 1953 illustrates the blending of Modernity and Tradition, in a series of experimental projects such the Market at Vila da Feria or the Tennis Pavillion in Matosinhos (1957). These works reflect the criticism made to international architecture.

Távora was interested in the "a-ideological" quality of architecture, and became interested in what is permanent - that makes irrelevant the style and therefore the ideology.

For him Modern Architecture is not a style, but the result of an attitude, that translate exactly the reality that involves. Távora created a tenuous articulation between/among local and global.

For the intention of this investigation, we have selected four case-studies to highlight their positions and critical thinking in Architecture, whose are the following: two projects from Le Corbusier, Ronchamp and Chandigarh, and for Fernando Távora we select other two projects, the Ofir House and the Market at Vila da Feira, both projects in Portugal. The selection of the projects is intentional because we attempt to analyse different project scales. This approach methodology allows us to identify the same attitude and critical thinking used during the creational process of both projects. In Chandigarh's example it is not our intention to analyse the entire project exhaustively, however we still focused on our own research fields, the global architects and their investigation on the dialectics between international and local issues.

\subsection{Chapel of Nôtre Dame du Haut, Ronchamp, 1950 - 1954}

"Architecture is the synthesis of the major arts. Architecture is form, volume, colour, acoustics, and music.",

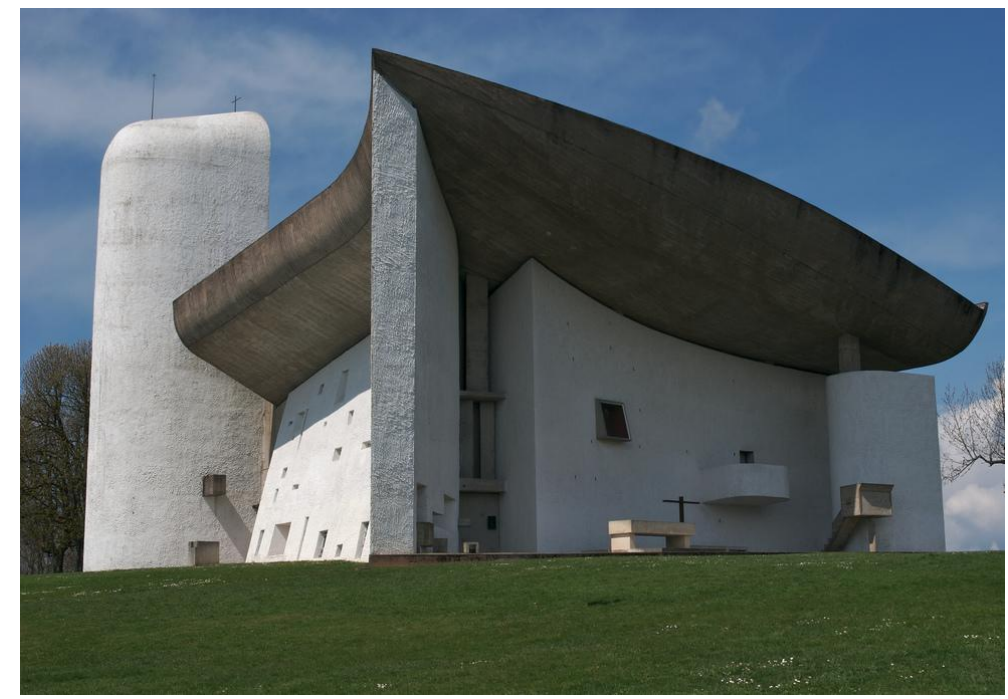

1. Chapel of Notre Dame du Haut, Ronchamp, France, Le Corbusier, 1950. In the east wall there is the open-air chapel.

Ronchamp is a Project for a pilgrimage chapel to accommodate 200 people, on a hilltop in the Vosges Mountains. The building is orientated traditionally, with the altar to the east side and the entrance to the west. The natural light in the building characterizes the space.

\footnotetext{
${ }^{4}$ Le Corbusier, Ronchamp (Carnets de la recherche patiente),17. (Apud: Moos, Stanislaus Von. Le Corbusier: Elements of a Synthesis,(1st Ed. 1979), Revised and expanded, Rotterdam: 010 Publishers, 2009, p. 266).
} 
As Curtis referred, this phase of Le Corbusier works seems to be the search for perennial and unchanging values, this is his primary motivation and let behind his quest for modernity ${ }^{5}$, that characterized all the work he made before. The Chapel of Ronchamp transcends the normal bounds of architecture with their profusion of spirituality and symbolic content, because it is above all sculptural and figurative creation. Lots of metaphors can be identified: the roof as a boat or a mushroom, the light towers as two people hugging each other or as a periscope. The chapel was conceived as a cave where Le Corbusier has used the light and many processes to create different auras as the main process. There are different windows with several colours that perforated a thick and curved wall, a reference to the Gothic Cathedral the symbol of devotion. The penumbra, that characterizes the space, contrast with the light that came from the layer above the roof, creating a filtered sunlight that passes through the glass. As Le Corbusier wrote "is the apotheosis of plastic emotion".

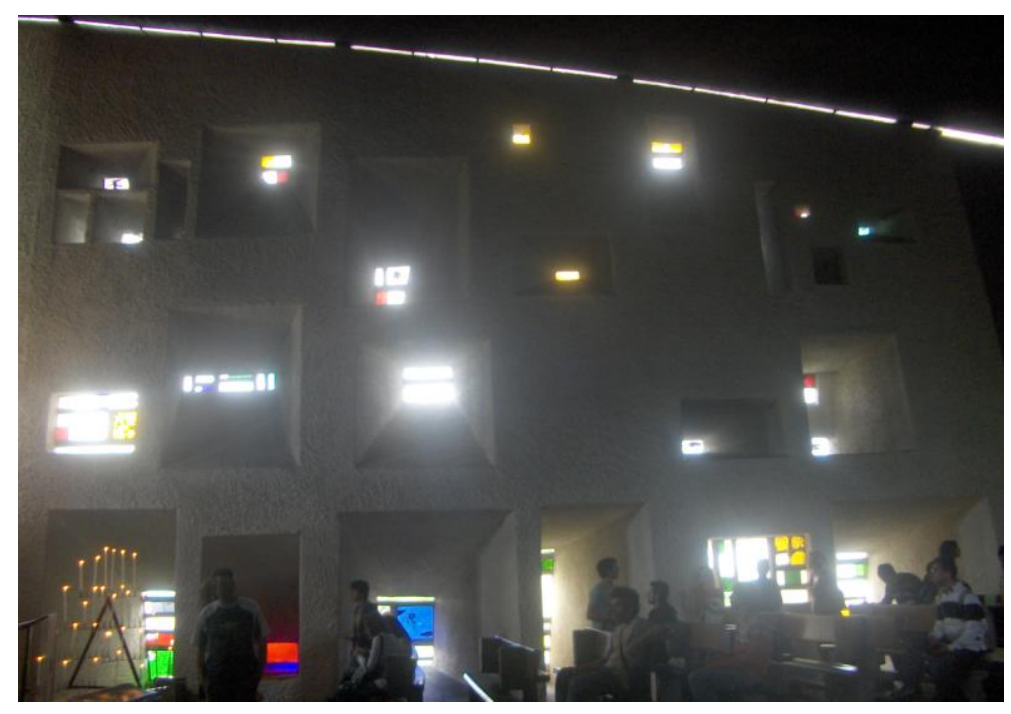

2. Ronchamp Interior View.

Le Corbusier denotes a delicate and sensitive work with light and its meaning. The wall ends before touching the roof and, it is where Le Corbusier puts a glass to create the illusion of suspension of the heavy rooftop. Le Corbusier is sensitive to the spiritual aesthetic of the Chapel, and combines the modern language of architecture with universal questions and meanings. These considerations of cultural and local circumstances were present in several works from this phase of Le Corbusier's Work.

3. Ronchamp Interior View. Fondation Le Corbusier, Paris. FLC 07412. @FLC-ADAGP.

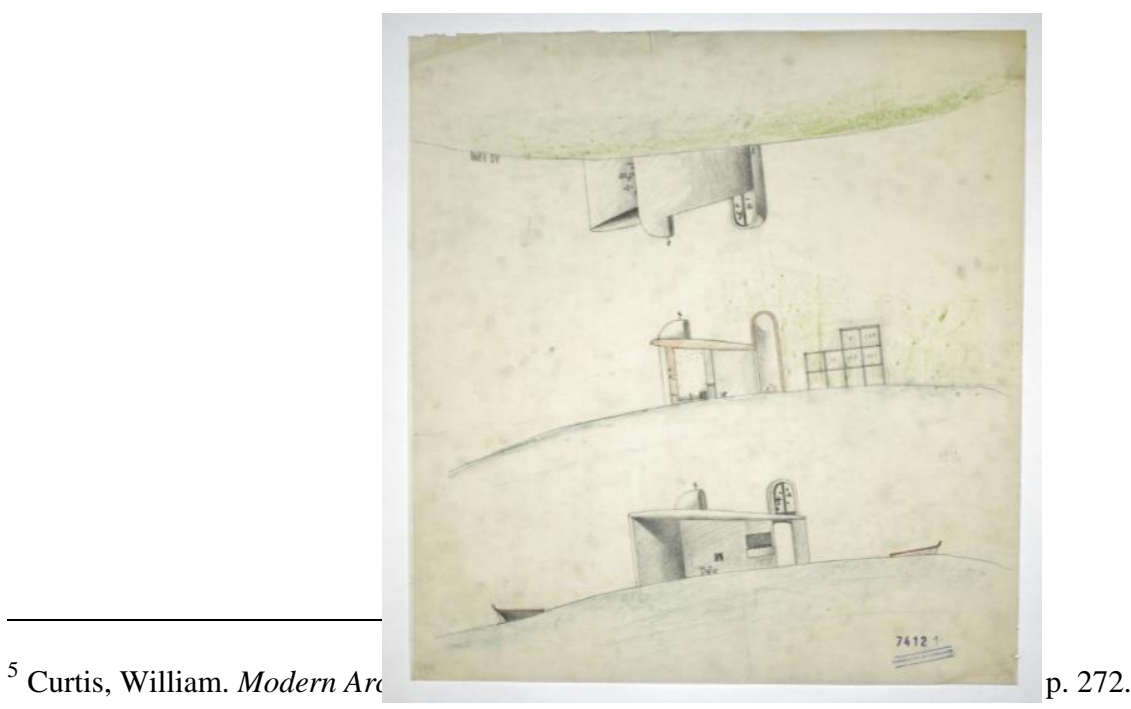




\subsection{Chandigarh as a rethinking of the modern city}

The Chandigarh's design begins with the desire of a new capital for the Punjab state in India. Nehru was the leader who dreamed with this capital, the symbol of democracy and peace. As Von Moos mention, "Le Corbusier's commitment to social harmony may have sounded more familiar to Indians ears than he himself suspected, for the belief in a universal brotherhood of man based upon the blessing of progress and technology ${ }^{6}$ [...]."

The city of Chandigarh was designed to 150000 people and governmental buildings such Parliament, Capitol, High Court and was planned to grow to 500000 people, a natural development to the city capital of the state.

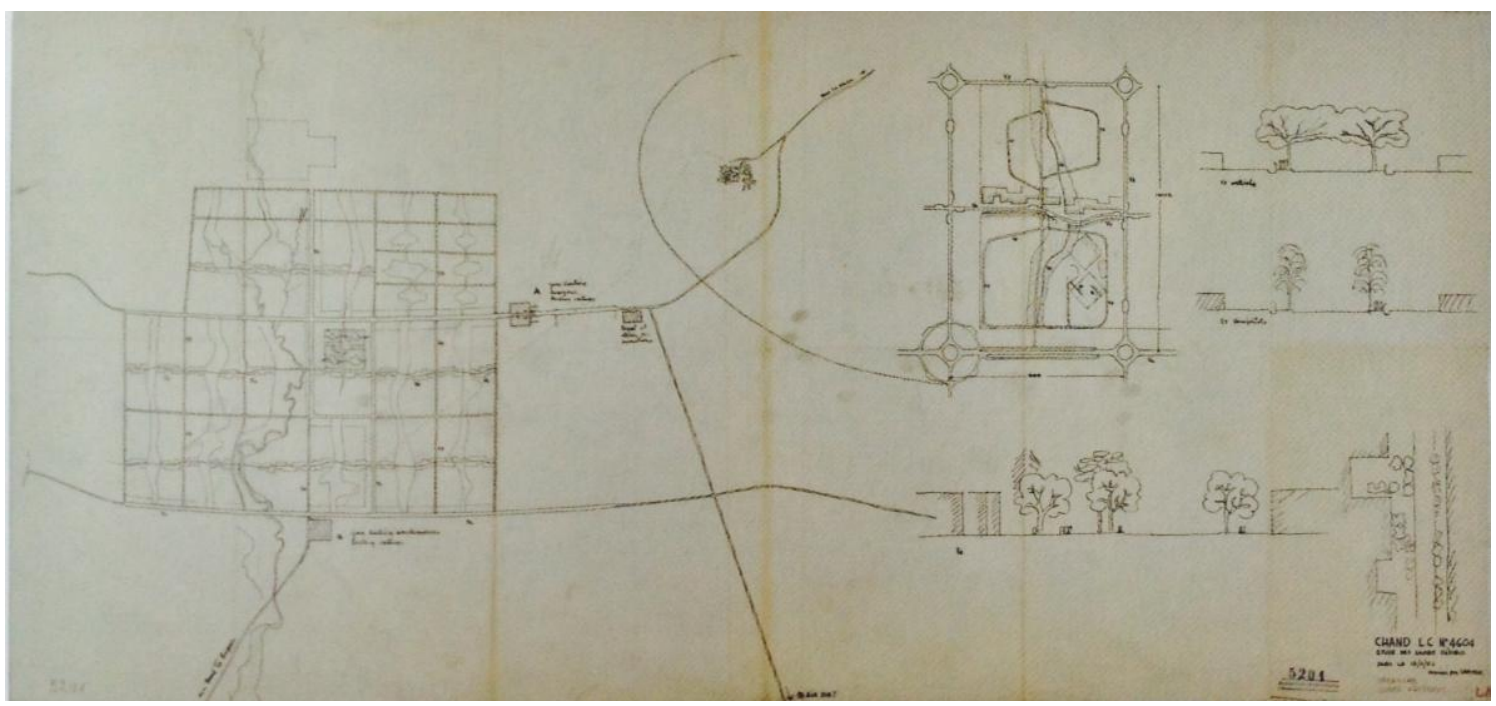

4. Plan of Chandigarh, showing transportation networks. 1951-65. Fondation Le Corbusier, Paris. FLC 05201. CFLCADAGP

Le Corbusier was the city master plan author. He also planned the vast Capitol Complex where major institutions are located, such as the High Court, Assembly, Secretariat and the Governor's Residence that was unbuilt. Jane Drew and Maxwell Fry composed the team responsible for the city conception ${ }^{7}$. The capital was conceived as a horizontal city with an artificial lake Sukhana that reflects the entire city, and also incorporates the layout of the Radiant City (La Ville Radieuse, 1930/5) but without à redent housing block.

It is an idea of his maturation period, as Curtis refers "Moreover [...] the post-war period in Europe was itself marked by pockets of resistance against sterile aspect of internationalism. The attitudes towards the vernacular intrinsic to the late works of Aalto, Le Corbusier and Team X, for example, suggested a more accommodating and flexible strategy with regard to local tradition."

\footnotetext{
${ }^{6}$ Moos, Stanislaus Von. Le Corbusier: Elements of a Synthesis, (1st Ed. 1979), Revised and expanded, Rotterdam: 010 Publishers, 2009, p290.

7 Prakash, Vikramaditya. Chandigarh's Le Corbusier: the struggle for Modernity in Postcolonial India. University of Washington Press Seattle \& London, 2002, p13

${ }^{8}$ Curtis, William J.R. Modern Architecture Since 1900, (1st ed. 1982), p.334.
} 


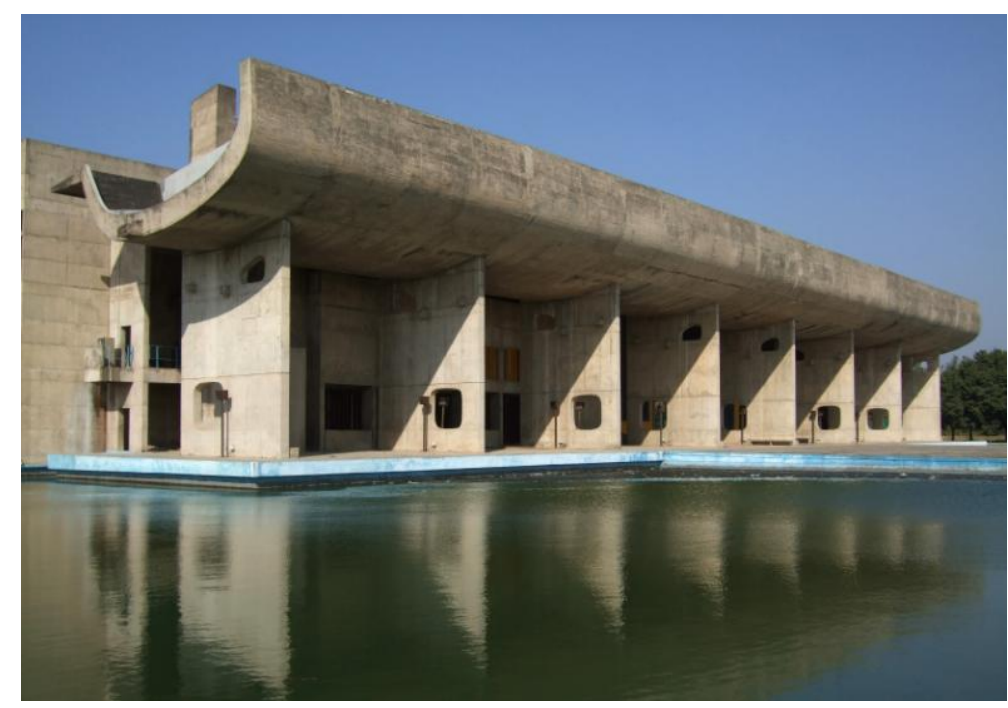

5. Palace of Assembly, Chandigarh. India, 1955. @ FLC/ADAGP

Chandigarh can be understood as the culmination of the symbolic creation, where Le Corbusier cast an inventory of primordial symbols such as sun, moon, lightening into the monuments but also his philosophical language from the Le Modulor, the harmonic spiral, the solar cycle and the "Open Hand".

However, Le Corbusier's rationalism did not disappear entirely, his concerns after the Second World-War included mathematics and more important The Modulor System. It is important to highlight that in 1946 Le Corbusier wrote "L'architecture et l'esprit mathemathique" and four years later publishes "The Modulor: A Harmonious Measure to The Human Scale, Universally Applicable to Architecture and Mechanics", which proposed a universal system of measurements for architecture based on golden section proportions.

Le Corbusier worked with typical Indian colours such as pink, colourless yellow, green, all them very different from the primary colours that he used in Unité d'Habitation in Marselha (1945), but in Chandigarh he suggests the coloured indian tissues drying on the sun. Le Corbusier celebrates the genius loci of the place: he incorporates influences from the surrounding area, such the erosional valley that suggests the grid orientation for the entire city in a way to merge landscape and natural environment with architecture and urban design 9 .

Corbusier seems to incorporate universalizing iconography on his works, also combining modern architecture with local culture, materials and methods, in a synthesis process. The balconies created a grid with brise-solei that protected the windows creating the main language of the city complex. He also worked with rugged concrete expression, which became an expression of the surface. The raw concrete finishes and the brise-soleil replaced the thin pilotis and horizontal windows from the beginning period of Le Corbusier.

\footnotetext{
${ }^{9}$ Casciato, Maristella. "Chandigarh: Landscaping a New Capital”, in Cohen, Jean-Louis. Le Corbusier: an atlas of modern landscapes, London: Thames \& Hudson, 2013, p.373.
} 


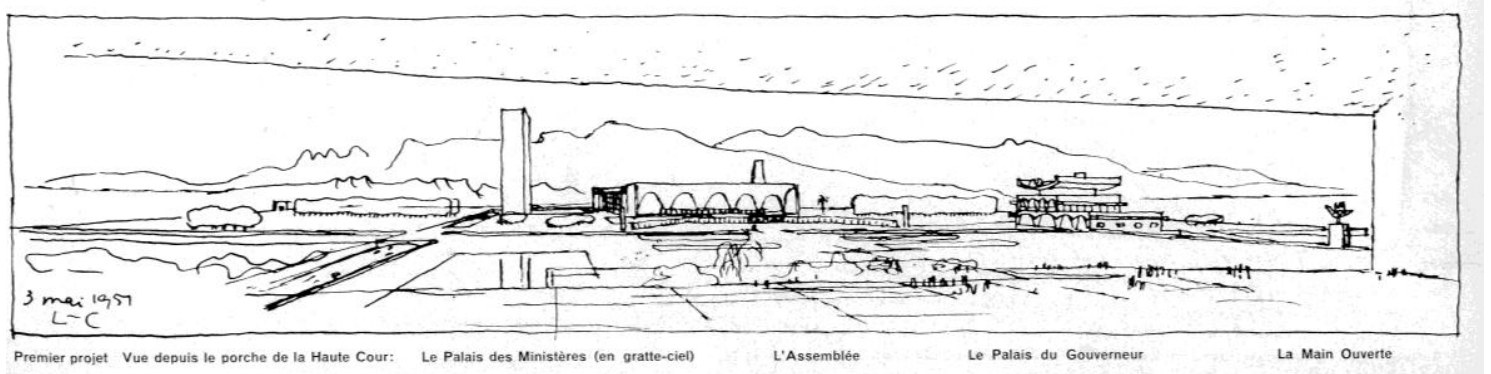

6. Oeuvre Complète, volume5, p.119. (C) FLC/ADAGP

Chandigarh's topography is almost flat with continuous vegetation, the horizontal line prevailing on the skyline. There are no "noble materials", only raw concrete that unite the entire complex, a brutalist experiment. The landscape is punctuated with some buildings and sculptures, which organized and make the delimitation of the site with almost 45 hectares, making them a good example of Land Art.

We can observe a cosmic sense as in Ronchamp Chapel, a building created as an enormous sculpture where a giant pyramid and its truncated conical skylight is combined with other forms, a metaphor of Jantar Mantar of Jaipur, a local blanket. Le Corbusier was careful with indian culture and respect it on his project. Although he still use a rational concept to hierarchize the city traffic road onto seven different types, from the highway till the pedestrian path and organize in several districts with the main functions, we can still identify a more organic plan that respect the local circumstances. Chandigarh seems to be his possibly last opportunity to achieve his target toward a new modern landscape and architecture.

\subsection{Ofir Summer House, (1957-1958) the search of the Third-Way}

Ofir Summer House is a vacation house located in a pinewood near Ofir's beach, in the North of Portugal. This project reflects a synthesis on the Portuguese Architect Fernando Távora path (1923-2005).

"It was through a permanent, magnificent and unforgettable dialogue, where everyone was involved in an attempt to achieve a true compound, that we accomplished our goal. As to its intrinsic value only the future, that great judge, will tell; as to the principle adopted, we have no doubt whatsoever that this is the only on to follow should we want our works, due to their individuality, to be recognized universally". ${ }^{10}$

Távora begins a pathway of permanent search on his formation, where the contradiction has become more persistent. The presence of opposites in architecture become more usual at his work and Távora was conscious about this fact and how it influenced both his works and his thinking. This process was named as Third Way in Architecture ("Terceira Via"/ $3^{\mathrm{a}} \mathrm{Via}$ ). In this attitude we recognize a manifesto of dialectics on international and local issues, or as Távora referred "la arquitectura tiene eso, que lo inverso también es verdade ${ }^{11}$ ".

Fernando Távora pursuit the integration of modernity and tradition, and he was always seeking to maintain coherence on his work and never betrayed his thoughts and opinions on architecture.

\footnotetext{
${ }^{10}$ Trigueiros, Luis. Fernando Távora, Blau, Lisboa, 1993, p. 80.

${ }^{11}$ Frechilla, Javier; "Fernando Távora. Conversaciones en Oporto", in Arquitectura 261, Julho-Agosto 1986.
} 


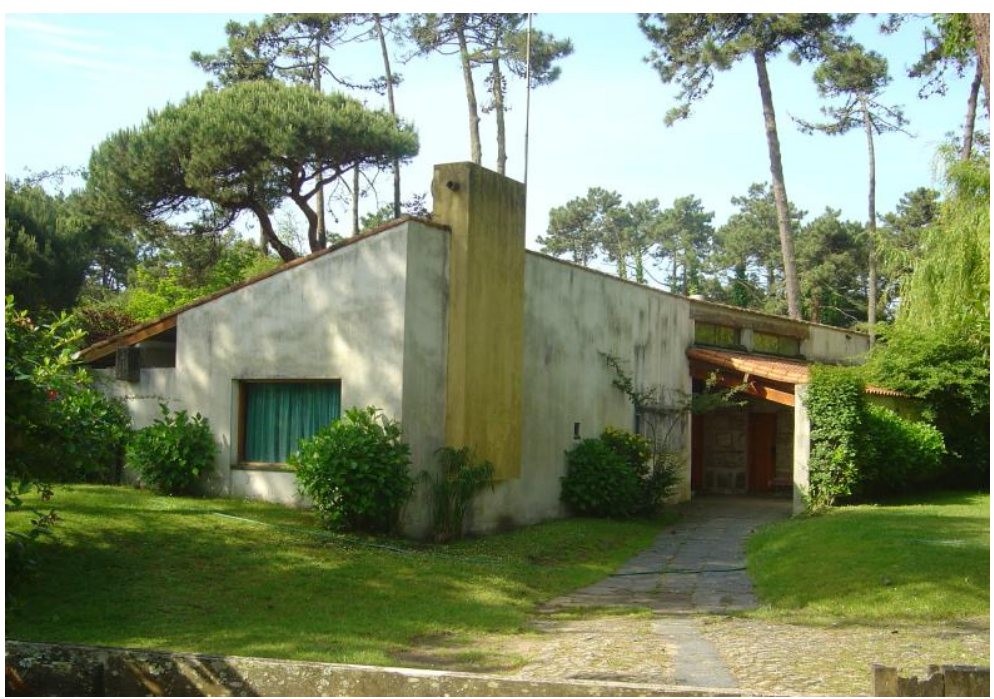

7. Summer House in Ofir. Portugal. Arch. Fernando Távora. View of the house entrance area: the path, the bench, and a little window that brings light into the house interior. It is important to highlight the presence of the yellow colour in the chimney, the only colour used in the house.

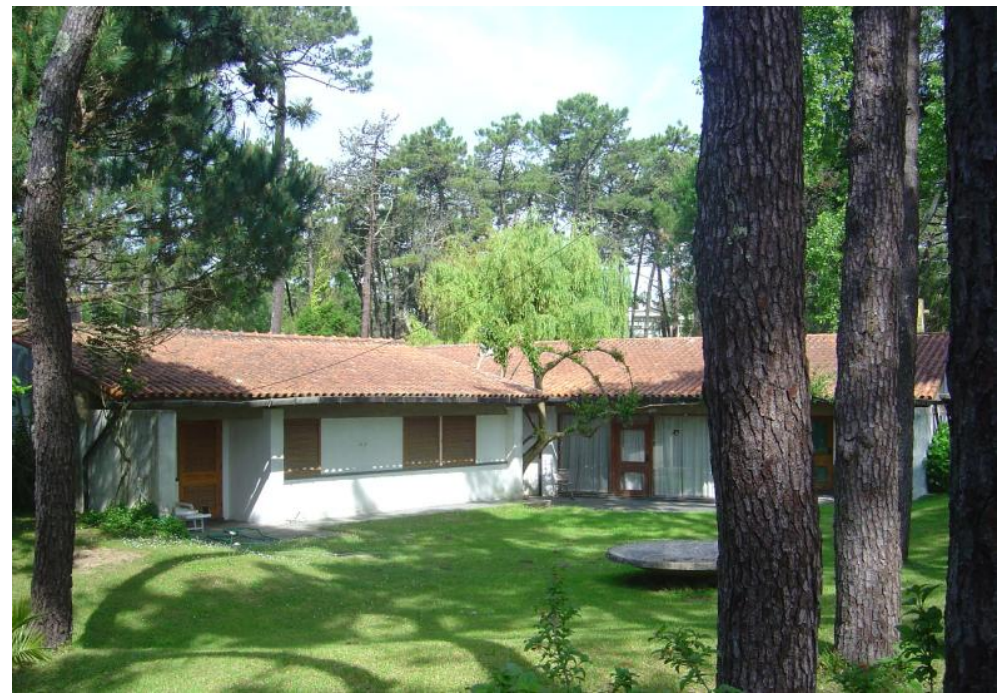

8. View of Ofir Summer House - a house among the trees.

In this summer house, we recognize Le Corbusier's influence in the use of raw concrete on the structure, also in the light effects of the openings such as de niches and windows that perforated the walls that create a tenuous light in the room which allude to the Ronchamp Chapel made by Le Corbusier. Távora blends the modern and the tradition in a synthesis of opposites values. The foundations are in uncovered stone masonry, the brick floor and some elements in large granite cobbles refer to the spontaneous architecture; the roof slopes to interior side and is supported by wooden structures made visible. The thick walls are painted in white and the chimney is in yellow, the only colour used in this project. Like in Ronchamp Chapel, here windows with several dimensions perforate randomly a thick wall.

Távora was aware of the necessary synthesis toward a new architecture, where is more important to blend than to mixture, and take in consideration a multiplicity of circumstances. Távora blends the house with its surroundings, in this case the pinewood, creating a new landscape.

\subsection{Market at Vila da Feira or the space and time contemplation}


The Market (1953-1959) is located in Vila da Feira and it is the expression for a new solution for the public facilities, as a new Market open to everyone, comparable as a Greek Ágora. The market is the result of an intellectual process about the integration of universal and local values ${ }^{12}$, to prove the possibility to synthetize opposites, creating the Third Way ( $3^{\text {rd }}$ Way), that is a Manifesto of articulation between local and global values and influences. Jean-Louis Cohen ${ }^{13}$ named this critical thinking as the "Critical Internationalism" in which rather than reacting defensively to the threat of a homogenizing modernization, the architects made a cautious and calculated decision.

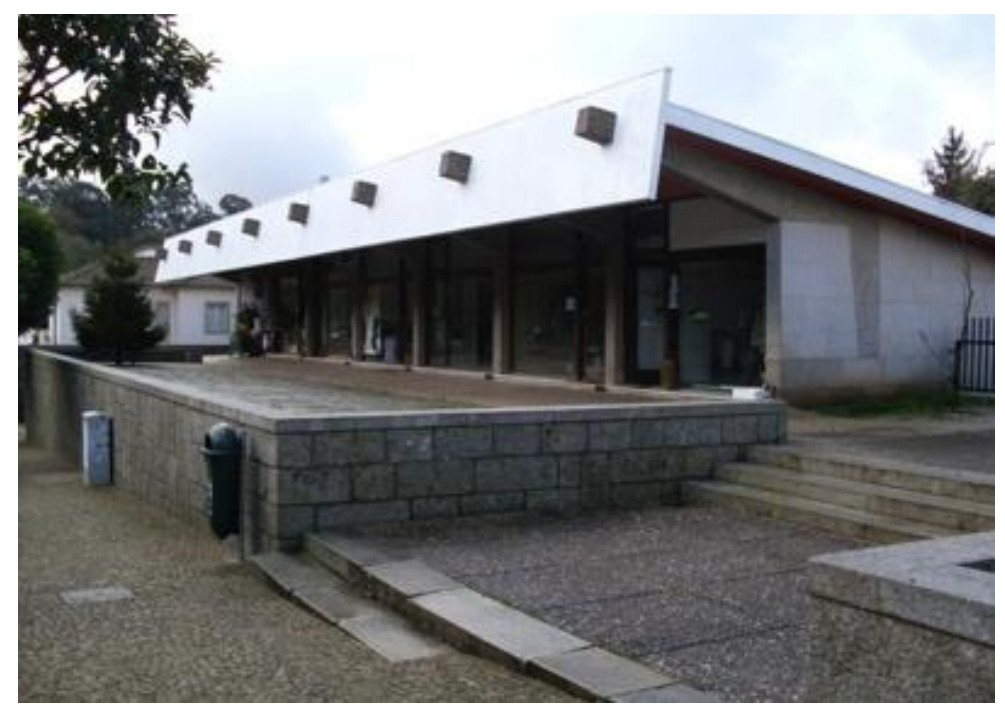

9. Entrance to the Market at Vila da Feira, Portugal. Fernando Távora.

In a 50x50m square lot Távora planned a market, based in an orthogonal grid of 1 by $1 \mathrm{~m}$ that create the geometry of composition. Although a rigid based grid, the volumes composition were fluid and with sober language. The medieval castle emerges in the surroundings. Four volumes distributed by two platforms, configured and delimited the space creating a centre courtyard where is located a fountain surrounded by an octagonal bench that marks the centre, the 'core' of the proposal, and therefore a clear influence of the CIAM VIII at Hoddesdon (1951) adopted in the work of the Arch. Távora.

Távora marks the centre of the place, in a classical gesture, which reveals his doubts about modernism ${ }^{14}$. However, he used the modern language in the structure, his need to mark the centre show us the doubts that he explores to the limits in the projects during the next decades.

We observe a strong reference at the Greek ágora, a place that combine the function of public facilities and also public space. First, we have a program of a market, which means a public space to trading functions, trading goods and ideas. It takes the canon of Greek agora, where besides the market function, also brings together the valences of meeting space for people, exchange ideas, a meeting space and permanence.

The placement is in an interior lot, adjacent to Rua dos Descobrimentos, where Távora proposes the creation of a public space in an interior lot, which one would assume private. The main street Rua dos Descobrimentos is

\footnotetext{
${ }^{12}$ Lima, Susana. "O espaço publico na obra de Fernando Távora - A importância do desenho do espaço público", in Sobre o 'projeto-de-arquitectura' de Fernando Távora; Fernando Távora : minha casa/ org. coord. Manuel Mendes, Porto: FIAJMS, 2005, p. 194-195.

${ }^{13}$ Cohen, Jean-Louis. The Future of Architecture. Since 1889, London: Phaidon, 2012.

${ }^{14}$ Esposito, Antonio; Leoni, Giovanni. Fernando Távora: opera complete. Milano: Electa, 2005.
} 
slopped allowing the existence of two platforms that organize the space hierarchically, one on the lower level and the other equivalent to the upper level of the market ${ }^{15}$.

The granitic base symbolise the connection to earth, a telluric link and on the other side, the four volumes that contours and organize the space are in concrete material, in a clear contrast with the stone. The concrete has made possible the inverted roof - "butterfly roof" with a large empty space between pillars. As we look at the plan we notice Neoplastic influences on walls dematerialization searching for an atectonic space, organized by the rooftop and pillars. They conform and organize the space, in which Távora inscribe a water-basin with an octagonal bench, as the centre of world. The materials chosen on this project indicate functional aspects but also structural, endurance and even aesthetics issues

The Virtuvian lessons were present on Távora's Works: the utilitas, firmitas and venustas.

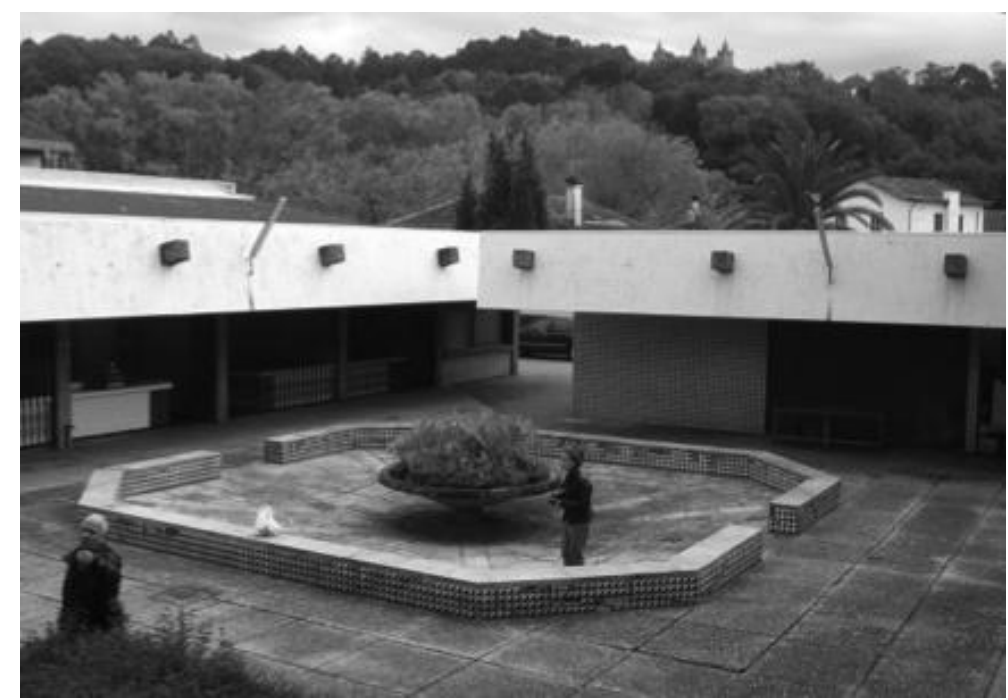

10. Market at Vila da Feira, Portugal. Centre view.

The concrete and steel structured the suspended roof. On other side, the stone and the tile, traditional materials from the north of Portugal enabled the connection to land and the traditional and local circumstances. Távora searched for integration of the modern architecture but questioning their value and made a return to endogenous materials and construction techniques and methods, a return to the origin, as Nietzsche taught.

Aldo Van Eyck analysed this project during the Otterlo Congress (CIAM, 1959), suggesting that the "current notion of time and space should be replaced by the more vital concept of place and occasion ${ }^{16, "}$

Távora explored, on this project, the specific identity of the place without breaking with classical modernism issues such the oppositions between nature and artefact but also the expression of technology. It becomes evident the adhesion to expressive techniques of Le Corbusier work in post war period, such as in the massive expression of the structure and the contrast materials, the use of colours, textures combined.

To sum, this Market results in an enriching expression of modernity, with international scope, because, on the one hand, it proposes a return to historical and cultural origins, on the other it embodies the named Third Way, the way of synthesis.

\footnotetext{
${ }^{15}$ Bandeirinha, J. António. Fernando Távora Modernidade Permanente. Edição Casa da Arquitectura, 2012.

${ }^{16}$ Trigueiros, Luis. Fernando Távora, Blau, Lisboa, 1993, p 56.
} 


\section{Conclusions}

In sum, Architecture is a universal phenomenon. It is more important its ethical function rather aesthetics, because when it is connected to life produce happiness for all inhabitants. These two architects that we have analyze and their works are the demonstration of a great capacity for coordination and synthesis of opposing values, in an integrated view in order to seek the correct and rational form that achieves efficient and beauty the synthesis necessary and possible.

We have chosen the last work from Le Corbusier, in the 1950's because nevertheless they proved to be the most prolific on his career. Ronchamp and even more Chandigarh demonstrate the turn he had taken in his approach to design. Távora inherit this legacy and also have made his own path in the scope for the universality in architecture and the synthesis in Architecture.

The importance of their contribution resides in how they looked at architecture, without refuse modernity and avant gard contributions, with a huge humanism combined with that modern spirit.

\section{Acknowledgements}

The organization acknowledges the directorship of Professor Teresa Fonseca, Fundação Instituto Marques da Silva (a private foundation established by Universidade do Porto) where is accommodated the Fernando Távora Archives, to Paula Abrunhosa, Ana Ramos and Conceição Pratas.

\section{Source of images}

Image 1. Ronchamp. Lima, Susana, 2009.

Image 2. Ronchamp. Lima, Susana, 2009.

Image 3. Ronchamp. Fondation Le Corbusier, Paris. 07412. OFLC-ADAGP.

Image 4. Plan of Chandigarh. Fondation Le Corbusier, Paris. 05201. OFLC-ADAGP.

Image 5. Palace of Assembly, Chandigarh 1. Fondation Le Corbusier, Paris. OFLC-ADAGP.

Image 6. Oeuvre Complète, volume5, p.119. (C) FLC-ADAGP.

Image 7. Casa de Ofir. Lima, Susana. Ofir (Esposende), Portugal, 2007.

Image 8. Casa de Ofir, Plan. Lima, Susana. Ofir, 2007.

Image 9. Mercado da Feira. Lima, Susana. Vila da Feira, Portugal, 2013.

Image 10. Mercado da Feira. Lima, Susana. Vila da Feira, Portugal, 2013.

\section{Bibliography/references}

Arquivo Arquitecto Fernando Távora, Fundação Instituto Marques da Silva - Universidade do Porto (AAFT FIMS).

Bandeirinha, J. António. Fernando Távora Modernidade Permanente. Edição Casa da Arquitectura, 2012

Cohen, Jean-Louis. Le Corbusier: an atlas of modern landscapes, London: Thames \& Hudson, 2013.

Cohen, Jean-Louis. The Future of Architecture. Since 1889, London: Phaidon, 2012.

Colomina, Beatriz. “Toward a Global Architect". In Architects' Journeys: Building, traveling, thinking. Pamplona: T6 Ediciones, 2011. 
Colomina, Beatriz. "Verso un architetto globale: Nel dopoguerra Le Corbusier ha trasformato la professione dell'architetto. Suo complice: il jet.” In Domus. New York, 30 April 2011.

Curtis, William. Modern Architecture Since 1900. London: Phaidon Press, 1991.

Esposito, Antonio; Leonni, Giovanni. Fernando Távora Opera Conpleta. Milano: Electa, 2005.

Fondation Le Corbusier.

Frechilla, Javier; "Fernando Távora. Conversaciones en Oporto”, in Arquitectura 261, Julho-Agosto 1986.

Le Corbusier. Cuando las catedrales eran blancas: viaje al pais de los timidos. trad. Marta Llorente. - Madrid: Apóstrofe, 2007.

Le Corbusier. Le Corbusier, My Work, London: Architectural Press, 1960.

Le Corbusier. When the Cathedrals Were White. New York, Toronto, London: McGraw-Hill Book Company, 1964, p. 32. Translated from the French by Francis E. Hyslop Jr

Lima, Susana. "O espaço público na obra de Fernando Távora - A importância do desenho do espaço público", in Sobre o 'projeto-de-arquitectura' de Fernando Távora; Fernando Távora : minha casal org. coord. Manuel Mendes, Porto: FIAJMS, 2005, p. 188- 213.

Moos, Stanislaus Von. Le Corbusier: elements of a synthesis. ( $1^{\text {st }}$ Ed. 1968) Rotterdam: 010 publishers, 2009.

Padovan, Richard. Towards universality: Le Corbusier, Mies and De Stijl, 1st ed. - London: Routledge, cop. 2002.

Prakash, Vikramaditya. Chandigarh's Le Corbusier: the struggle for Modernity in Postcolonial India. University of Washington Press Seattle \& London, 2002.

Trigueiros, Luis. Fernando Távora, Blau, Lisboa, 1993. 